\title{
PENGEMBANGAN MODEL PEMBELAJARAN STS (SCIENCE-TECHNOLOGY SOCIETY) UNTUK MENINGKATKAN KEPEDULIAN MAHASISWA TERHADAP LINGKUNGAN HIDUP PADA MATAKULIAH EKOLOGI MANUSIA
}

\author{
Wanjat Kastolani, Mamat Ruhimat \\ Dosen Pendidikan Geografi FPIPS UPI \\ E-mail: wanjat_pci@yahoo.co.id
}

\begin{abstract}
ABSTRAK
Penelitian ini bertujuan ingin mengetahui proses identifikasi masalah lingkungan hidup yang dapat dilakukan mahasiswa pada matakuliah Ekologi Manusia, mengembangkan prosedur model pembelajaran STS pada matakuliah Ekologi Manusia, dan membandingkan tingkat efektivitas model pembelajaran STS dengan model konvensional yang selama ini dilakukan pada perkuliahan Ekologi Manusia. Disain Eksperimen yang akan digunakan adalah Pretest-postest, Non-Equivalent Control Group Design. Dengan design ini, subjek penelitian ditest sebelum mendapat perlakuan (pretest). Pretest dalam desain penelitian ini digunakan untuk pengontrolan secara statistic (statistical control) dan untuk melihat pengaruh perlakuan terhadap capaian skor (gain score). Hasil penelitian menunjukkan bahwa hasil test awal (pretest) nilai rata-rata yang diperoleh oleh responden hanya 17,0 dari 40 soal yang diajukan artinya jauh di bawah rata-rata. Standar deviasi dari rangkaian skor nilai adalah sekitar 4,8. Selanjutnya dari data hasil posttest ada kenaikan rata 22,7 yang menjawab dengan benar dari 40 soal. Dengan demikian, sudah dapat disimpulkan bahwa metode STS dapat meningkatkan prestasi mahasiswa.
\end{abstract}

Keywords: STS teaching and learning model, students' awareness, environment

\section{ABSTRACT}

The research aimed at understanding identification process of problems in environment which was done to students enrolling in human ecology subject in their undergraduate study. The research also developed procedures of implementing STS teaching model in the aforementioned subject. The research then analyzed results of the implementation of STS teaching model in comparison to the conventional one, usually having been implemented before the research, to measure the level of effectiveness. The design of the experiment in the conduct of the research employed pretest-posttest, non-equivalent control group design. With this design, the research collected students' attainment prior to the treatment of STS (pretest). The collection then informed the research to engineer statistical control over the students' learning activities, as well as investigate the influence of STS treatments towards the gain of their score. The findings of the research exemplified that students' pretest scores only accomplished answering the 40 provided test items correctly in average points of 17,0. This was measured to be significantly below standard. The deviation stardard out of the set of students'scores was around 4,8. Compared to posttest score attainment, there was a significant rise falling into 22,7 points of students' answering the 40 test items. Thus, it is clearly denoted that STS teaching and learning model enhanced students' achievements.

Keywords: STS teaching and learning model, students' awareness, environment

\section{PENDAHULUAN}

Matakuliah ekologi manusia merupakan mata kuliah yang bertujuan untuk memberi pemahaman teoritis ekologi manusia dan pengalaman praktis mahasiswa dalam usaha meneyimbangkan lingkungan hidup manusia. Pada jurusan pendidikan geografi FPIPS Universitas Pendidikan Indonesia, proses pembelajaran Ekologi Manusia telah melakukan berbagai terobosan untuk meningkatkan kompetensi mahasiswa baik yang berkenaan dengan cara mengidentifikasi masalah lingkungan hidup, mengumpulkan data yang terkait dengan masalah, maupun memberikan alternatif pemecahan masalah. Namun demikian hasil proses pembelajaran masih belum optimal dalam menyentuh ranah tujuan afektif dalam kehidupan mahasiswa sehari-hari.

Dalam rangka meningkatkan proses dan 
hasil pembelajaran pada matakuliah Ekologi Manusia, sebagaimana digambarkan di atas maka dalam penelitian ini akan dicoba suatu pendekatan atau model pembelajaran Science-Technology-Society (STS). Harapan melalui pengembangan model STS (ScienceTechnology-Society) adalah akan memberikan pengalamanpraktisterhadapmahasiswadalam menyelesaikan masalah lingkungan dengan cara melakukan penelitian yang sistematis yatu diawali dari cara mengidentifikasi masalah, mengumpulkan data yang terkait dengan masalah, memberikan alternatif pemecahan masalah, dan terutama sekali bagaimana cara pengembalian keputusan terhadap masalah tersebut.

Berdasarkan penjelasan di atas, dirumuskan masalah penelitian: (1) Bagaimana proses identifikasi masalah lingkungan hidup yang dapat dilakukan mahasiswa pada matakuliah Ekologi Manusia; (2) Bagaimana bentuk dan prosedur model pembelajaran STS pada matakuliah Ekologi manusia; dan (3) Apakah model pembelajran STS lebih efektif dibandingkan dengan model pembelajaran konvensional pada perkuliahan Ekologi Manusia.

Tujuan penelitian ini adalah ingin mengetahui proses identifikasi masalah lingkungan hidup yang dapat dilakukan mahasiswa pada matakuliah Ekologi Manusia, Mengembangkan prosedur model pembelajran STS pada matakuliah Ekologi Manusia, dan membandingan tingkat efektivitas model pembelajaran STS dengan model konvensional yang selama ini dilakukan pada perkulihan Ekologi Manusia.

Banyak pendekatan yang dapat digunakan dalam proses pembelajaran. Namun demikian, Anderson secara garis besar membaginya atas dua pendekatan, yakni teacher centered (terpusat pada guru) dan student centered (terpusat pada siswa).

Agar tercipta pembelajaran yang efektif, perlu digunakan pendekatan yang tepat. Pemilihan pendekatan pembelajaran hendaknya didasarkan atas beberapa pertimbangan. Sukmadinata (2004) memberi ramburambu pemilihan pendekatan pembelajaran yang tepat antara lain mempertimbangkan pencapaian kompetensi, karakteristik materi pelajaran, kemampuan siswa, dan kemampuan guru. Pencapaian kompetensi terkait dengan indikator yang akan dicapai dalam suatu pembelajaran: apakah pencapaian ranah kognitif, afektif atau psikomotor. Karakteristik materi pelajaran berkenaan dengan konstruksi, struktur, dan substansi dari bidang ilmu bersangkutan. Kemampuan siswa berkenaan dengan kapasitas, minat dan motivasi siswa. Sedangkan kemampuan guru berkenaan dengan latar belakang pendidikan dan keterbatasan-keterbatasan guru.

Ada beberapa pendekatan pembelajaran yang memiliki karakteristik student centered, yaitu pendekatan Pembelajaran Kontekstual (Contextual Teaching and Learning), pendekatan mencari dan bermakna yang dikemukakan oleh Ausubel dan Robinson (1968), pendekatan pembelajaran berbasis pengalaman merupakan suatu proses belajar-mengajar yang menekankan pada pengalaman siswa, baik pengalaman individual, emosional, sosial maupun fisikmotorik, dan pendekatan pembelajaran Science-Technology-Society (STS).

Science-Technology-Society (STS) sebagai pendekatan pembelajaran memberi kesempatan kepada siswa untuk menghargai sains dan teknologi dalam memberi konstribusi pada pengetahuan dan pengetahuan baru. Karli dan Yuliariatiningsih (2002) mengemukakan bahwa dalam pembelajaran STS terdapat 4 tahapan yaitu invitasi, eksplorasi, penjelasan dan solusi, serta pengambilan tindakan.

Tahap invitasi, mahasiswa didorong agar mengemukakan pengetahuan awal tentang konsep yang dibahas. Dosen memancing dengan memberi pertanyaanyangproblematic tentang fenomena alam yang ditemui 
sehari-hari dengan mengaitkan konsepkonsep yang dibahas. Mahasiswa diberikan kesempatan untuk mengkomunikasikan, mengikutsertakan pemahamannya terhadap konsep tersebut.

Tahap eksplorasi, mahasiswa diberi kesempatan untuk menyelidiki dan menemukan konsep melalui pengumpulan, pengorganisasian, penginterpretasian data dalam suatu kegiatan yang telah dirancang bersama dengan dosen. Secara berkelompok atau individu siswa melakukan kegiatan dan diskusi.

Tahap penjelasan dan solusi, saat mahasiswa memberikan penjelasan-penjelasan solusi yang didasarkan pada hasil observasinya ditambah dengan penguatan dosen, maka mahasiswa dapat menyampaikan gagasan, membuat model, membuat rangkuman dan kesimpulan.

Tahap pengambilan tindakan, siswa dapat membuat keputusan, menggunakan pengetahuan dan keterampilan, berbagai informasi dan gagasan, mengajukan pertanyaan lanjutan, mengajukan saran baik individu maupun masyarakat yang berhubungan dengan pemecahan masalah.

Model pengembangan STS ini dapat diterapkan baik pembelajaran pada rumpun Ilmu Pengetahuan Alam maupun IPS. Remy (1990) pernah membuat studi kasus untuk pembinaan kewarganegaraan yang baik sebagai salah satu tujuan dari pendidikan studi sosial. Pengintegrasian antara sains dan teknologi dengan studi sosial ternyata dapat membantu pencapaian tujuan pembelajaran. Agenda kebijakan publik yang diorientasikan pada technology-science dikaitkan dengan dampakanya terhadap kehidupan sosial dan juga sebaliknya.

Sejumlah penelitian yang telah dilakukan mahasiswa baik skripsi, tesis, dan disertasi diperoleh kesimpulan bahwa Sains Teknologi Masyarakat sebagai pendekatan dapat menjangkau siswa yang tergolong pada kelompok berkemampuan rendah dalam kelas karena dirasakan oleh siswa lebih menarik, nyata, dan aplikatif. Beberapa peneliti juga telah melaksanakan penilaian terhadap keenam ranah dan pendekatan Sains Teknologi Masyarakat. Dari analisis terhadap penelitian-penelitian yang telah dilakukan, tampak adanya pola tertentu dan langkah-langkah yang dilakukan dalam proses pembelajaran sebagai berikut (Poedjiati,2005).

Kekhasan dari model ini adalah bahwa pada

Tahap 1

Tahap 2
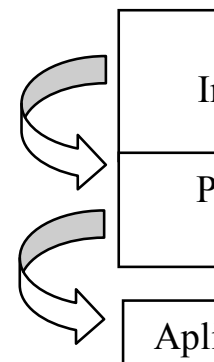

Pendahuluan: Inisiasi/

Invitasi/Apersepsi/Eksplorasi Terhadap Siswa

Pembentukan/Pengembangan Konsep

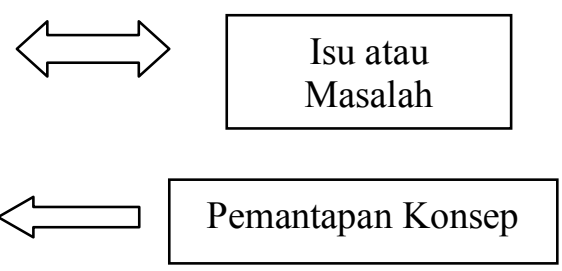

Tahap 3

Tahap 4

Tahap 5
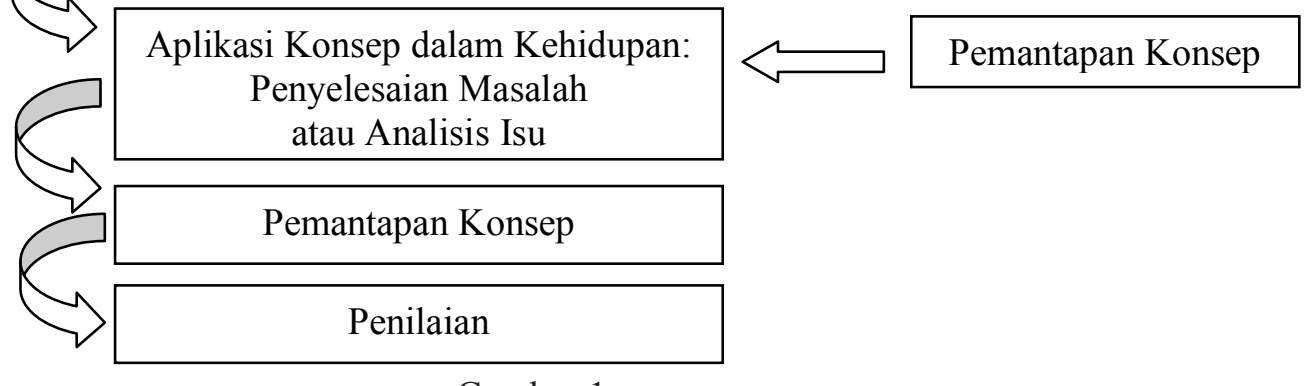

Gambar 1

Tahapan proses STS menurut Poedijati (2002) 
pendahuluan dikemukakan isu-isu atau masalah yang ada di masyarakat yang dapat digali dari siswa, tetapi apabila guru tidak berhasil memperoleh tanggapan dari siswa dapat saja dikemukakan oleh guru sendiri. Tahap ini dapat disebut dengan inisiasi atau mengawali, memulai, dan dapat pula disebut dengan invitasi yaitu undangan agar siswa memusatkan perhatian pada pembelajaran.

Apersepsi dalam kehidupan juga dapat dilakukan, yaitu mengaitkan peristiwa yang telah diketahui siswa dengan materi yang akan dibahas, sehingga tampak adanya kesinambungan pengetahuan, karena diawali dengan hal-hal yang sudah diketahui siswa sebelumnya yang ditekankan pada keadaan yang ditemui dalam kehidupan seharihari. Pada dasarnya apersepsi merupakan proses asosiasi ide baru dengan yang sudah dimiliki sebelumnya oleh seseorang. Pada pendahuluan ini guru juga dapat melakukan eksplorasi terhadap siswa melalui pemberian tugas untuk melakukan kegiatan di lapangan atau di luar kelas secara berkelompok.

Kegiatan mengunjungi dan mengobservasi keadaan di luar kelas itu bertujuan untuk mengaitkan antara konsep-konsep atau teori yang dibahas di kelas dengan keadaan nyata yang ada di lapangan. Dengan mendiskusikan temuan mereka, merencanakan tindakan selanjutnya, terjadilah kolaborasi dan koordinasi dalam kelompok. Ide-ide seseorang yang diterima kelompok dan direncanakan untuk dilakukan, merupakan kebanggaan tersendiri sehingga orang tersebut merasa dihargai, yang pada gilirannya akan mau berpikir terus untuk kebaikan dan penghargaan kelompok lain terhadap kelompoknya.

Dari proses penjelasan di atas, akhirnya Poedjiati (2005) menegaskan bahwa model pembelajaran Sains Teknologi Masyarakat dalam ilmu-ilmu sosial dan humaniora pada dasarnya memberikan pemahaman tentang kaitan antara sains teknologi dan masyarakat merupakan wahana untuk melatih kepekaan penilaian peserta didik terhadap dampak lingkungan sebagai akibat perkembangan sains dan teknologi. Di samping itu metode diskusi, bermain peran bekerja kelompok memberikan kesempatan kepada peserta didik untuk berkoordinasi dan berkolaborasi antar sesama teman, disamping dapat menyampaikan ide-ide serta saran untuk mendengarkan pendapat orang lain, perlu dihayati oleh setiap siswa. Model Sains Teknologi Masyarakat ini dapat diterapkan pada berbagai macam disiplin ilmu, namun perlu memilih tema yang tepat yang diambil dan silabus mata pelajaran.

Perlu diketahui bahwa tidak semua kajian dapat sesuai apabila menggunakan model ini, sehingga model ini hanya merupakan alternatif dari berbagai model yang ada. Penggunaan model pembelajaran Sains Teknologi Masyarakat di Indonesia harus tetap mengikuti silabus yang ada dan sesuai jenjangnya hal ini berbeda denga keadaan dunia pendidikan di negara maju.

\section{METODE PENELITIAN}

Rancangan penelitian ini adalah menggunakan penelitian Kuasi Eksperimen yaitu menggunakan seluruh subjek dalam kelompok belajar (intact group) untuk diberi perlakuan (treatment) bukan menggunakan subjek yang diambil secara acak. Desain eksperimen yang akan digunakan adalah Pretest-postest, Non-Equivalent Control Group Design. Dengan design ini, subjek penelitian ditest sebelum mendapat perlakuan (Pretest). Pretest dalam desain penelitian ini digunakan untuk pengontrolan secara statistik (statistical control) dan untuk melihat pengaruh perlakuan terhadap capaian skor (gain score).

Rancangan penelitiannya adalah sebagai berikut: 


\section{Intact classes}

Klas-1

Pretest

$\mathrm{O} 1 \longrightarrow$

Desain ini untuk mengetahui tingkat pengaruh model pembelajaran STS berdasarkan hasil test. Ukuran keberhasilannya adalah kemampuan mahasiswa dalam, mengidentifikasi masalah, mengumpulkan data, melahirkan solusi yang tepat, dan perubahan sikap. Secara keseluruhan dinamakan kompetensi penyelesaian masalah. Oleh karena itu hipotesis statistik yang diajukan adalah:

Hi: Ada perbedaan hasil test kopentensi mahasiswa sebelum dan setelah mengikuti proses pembelajaran melalui pendekatan STS pada matakuliah Ekologi Manusia

Ho: tidak ada perbedaan hasil test kopentensi mahasiswa sebelum dan setelah mengikuti proses pembelajaran melalui pendekatan STS pada matakuliah Ekologi Manusia

Subjek penelitian ini adalah mahasiswa Geografi yang mengontrak matakuliah mahasiswa program S1 dengan jumlah 71 orang. Pada semester genap 2005/2006 didominasi oleh mahasiswa angkatan 2004 yang seharusnya merupakan dikontrak untuk semester 6. Waktu pelaksanaan penelitian dimulai bulan Januari 2006 dan berakhir

\section{Experimental variable Posttest}

\section{Pendekatan STS $\longrightarrow \mathrm{O} 2$}

sampai pada bulan April 2006.

Istrumen yang dugunakan adalah test yang terdiri dari dua bentuk yaitu test kompetensi dan test sikap kepedulian mahasiswa terhadap lingkungan sekitarnya. Pada instrument tes kompetensi dilakukan uji validasi dan reliabilitasi. Jumlah soal terdiri dari 40 butir soal. Ruang lingkup atau kisi-kisi soal adalah sebagai berikut:

Analisis data akan dilakukan secara deskriptif yaitu hasil interpretasi table frekwensi dan hasil uji beda statistik hasil pretest dan posttest. Table-tabel frekwensi dari skala sikap kepedulian terhadap lingkungan hidup akan diketahui bahwa mahasiswa peduli dan tidak peduli terhadap lingkungan hidupnya.

\section{HASIL PENELITIAN DAN PEMBAHASAN}

Sesuai rencana, dalam pelaksanaan pembelajaran di kelas, pendekatan pembelajaran Science-Technology-Society (STS) mengikuti empat langkah yaitu invitasi, eksplorasi, penjelasan dan solusi (Karli dan Yuliariatiningsih,2002). Dari analisis tehadap penelitian-penelitian yang telah dilakukan, tampak adanya pola tertentu dan langkah-langkah yang dilakukan

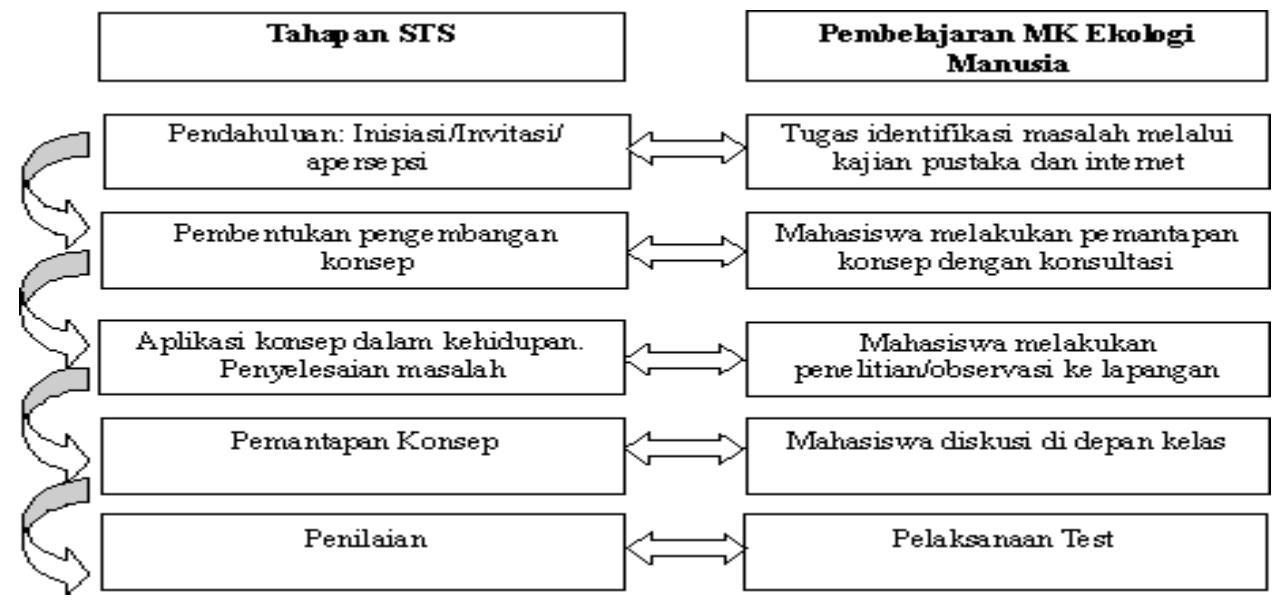

Gambar 2

Tahapan proses STS pada Mata Kuliah Ekologi Manusia 
dalam proses pembelajaran sebagai berikut (poedjiati, 2005).

Karena kehidupan manusia sangat erat dengan lingkungan hidupnya, mahasiswa yang belajar tentang ekologi tentu saja sudah familier dengan lingkungan sekitarnya. Pengetahuan mahasiswa dari lingkungan, dapat dijadikan modal dalam proses pembelajaran. Namun sebagai refleksi dari pembelajaran yang menggunakan pendekatan STS adalah bahwa observasi langsung pada praktek kerja memungkinkan digunakan untuk identifikasi kebutuhan belajar siswa dalam hal kepribadian, sikap, pengalaman, dan keterampilan. Dengan menggunakan observasi langsung, mahasiswa dapat dinilai pada kinerjanya. Namun demikian, penggunaan tugas pada STS selain membutuhkan waktu yang lama biasanya menghadapi dua masalah pokok, Yaitu: (1) siswa merasa dibebani tugas yang berat, dan (2) prasangka (subjektivitas) observer mempengaruhi terhadap validitas dan reabilitas penilaian pada saat mahasiswa tampil dalam acara diskusi.

Pendekatan STS umumnya didominasi oleh metode tugas dan atau project. Perbedaan antara tugas dan projek terletak pada waktu penyelesaian pekerjaan. Tugas umumnya lebih singkat daripada projek. Selain itu, pada projek siswa menentukan parameter pekerjaannya dengan seluruh petunjuk. Sedangkan pada tugas, parameter ditentukan guru. Pada projek, terbuka untuk berbeda jalan dan arahnya sedangkan tugas sangat dibatasi guru. Projek cenderung studentcenter learning approaches sedangkan tugas sebaliknya yaitu berpusat pada guru.

Hasil test awal (pretest) diketahui bahwa nilai rata-rata yang diperoleh oleh responden hanya 17,0 dari 40 soal yang diajukan artinya jauh dibawah rata-rata. Standar deviasi dari rangkaian skor nilai adalah 4,8. Sebaran mahasiswa yang menjawab soal dengan

Tabel 1

Sebaran Skor Nilai Pretset

\begin{tabular}{cccc}
\hline No & $\begin{array}{c}\text { Jumlah nomor soal yang } \\
\text { dijawab benar }\end{array}$ & Frekwensi responden & $\%$ \\
\hline 1 & $1-5$ & 1 & 1.4 \\
\hline 2 & $6-10$ & 6 & 8.5 \\
\hline 3 & $11-15$ & 20 & 28 \\
\hline 4 & $16-20$ & 26 & 37 \\
\hline 5 & $21-25$ & 16 & 23 \\
\hline 6 & $26-30$ & 2 & 2.8 \\
\hline 7 & $31-35$ & 0 & 0 \\
\hline 8 & $36-40$ & 0 & 0 \\
\hline & Jumlah & 71 & 100 \\
\hline
\end{tabular}

Sumber: Hasil Penelitian, 2006

Jika ditampilkan dalam grafik maka akan

berbentuk seperti di bawah ini:

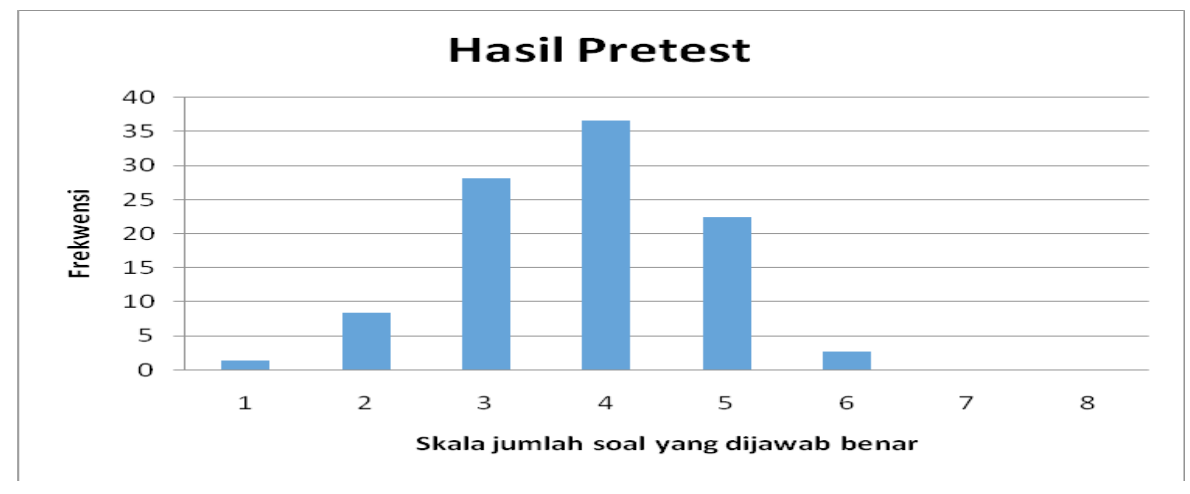


benar adalah seperti dalam tabel 1 .

Berdasarkan gambar grafik di atas tampak bahwa secara keseluruhan responden memiliki pengetahuan atau wawasan tentang sains dan teknologi yang diterapkan dalam penanganan masalah lingkungan hidup masih rendah.

Selanjutnya hasil posttest dari soal yang sama

Tabel 2

Sebaran Skor Nilai Posttest

\begin{tabular}{cccc}
\hline No & $\begin{array}{c}\text { Jumlah nomor soal yang } \\
\text { dijawab benar }\end{array}$ & Frekwensi responden & $\%$ \\
\hline 1 & $1-5$ & 0 & 0 \\
\hline 2 & $6-10$ & 1 & 1.4 \\
\hline 3 & $11-15$ & 4 & 5.6 \\
\hline 4 & $16-20$ & 16 & 23 \\
\hline 5 & $21-25$ & 34 & 48 \\
\hline 6 & $26-30$ & 13 & 18 \\
\hline 7 & $31-35$ & 3 & 4.2 \\
\hline 8 & $36-40$ & 0 & 0 \\
\hline \multicolumn{4}{c}{ Jumlah } \\
\hline
\end{tabular}

Nampak ada kenaikan yaitu ada kenaikan

Dari data hasil posttest ada kenaikan ratarata 22,7 yang menjawab dengan benar dari
40 soal jika ditampilkan dalam grafik dapat dilihat sebagai berikut:

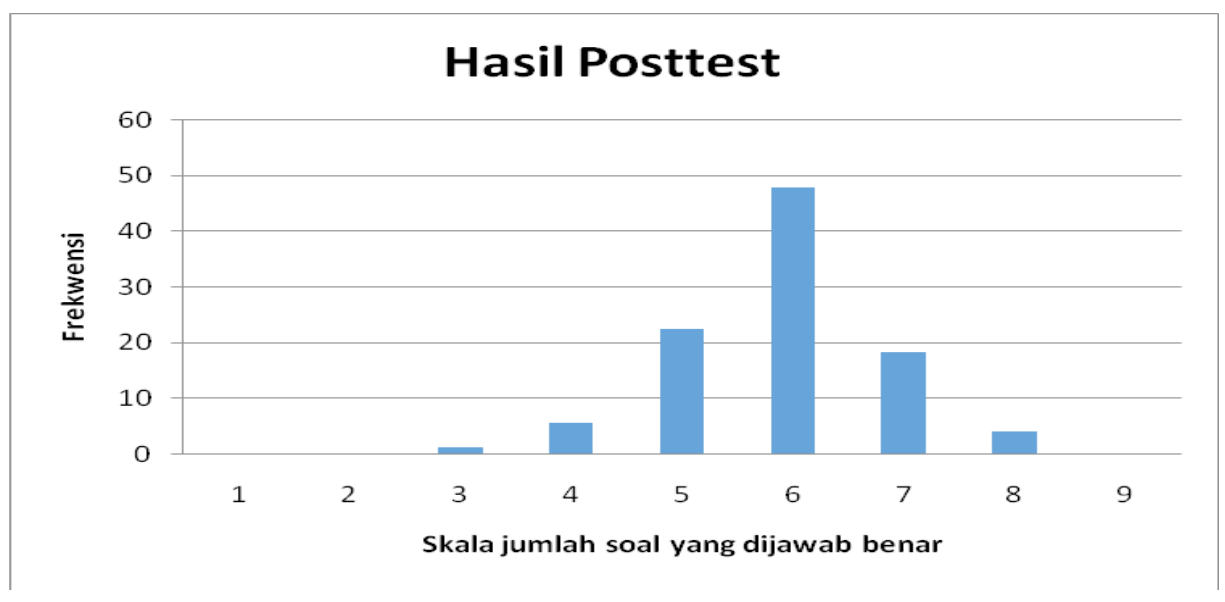

Untuk mengetahui tingkat pengaruh perlakukan melalui model pembelajaran STS ditampilan asil test secara keseluruhan dalam lampiran. Dilihat dari rata-rata hasil pretest dan posttest Nampak bahwa ada kenaikan rata-rata nilai mahasiswa. Dengan demikian, sudah dapat disimpulkan bahwa metode STS dapat meningkatkan prestasi mahasiswa.

Selanjutnya dengan asumsi bahwa seseorang yang memiliki literasi sains dan teknologi, adalah yang memilki kemampuan menyelesaikan masalah menggunakan konsep-konsep sains yang diperoleh, dalam pendidikan sesuai jenjangnya, mengenal produk teknologi yang ada produk teknologi dan memeliharanya, kreatif membuat hasil teknologi yang disederhanakan dan mampu mengambil keputusan berdasarkan nilai.

Adanya nilai positif antara literasi sains terhadap perilaku seseorang. Herlen dalam sholahudin (2001), menyarankan agar dalam pengajaran (Ilmu Pengetahuan Alam) dapat mengembangkan sikap ilmiah (scientific attitude) seperti sikap ingin tahu (curiosity), 
kebiasaan mencari bukti sebelum menerima pernyataan (respect for evindence), sikap luwes dan terbuka dengan gagasan ilmiah (flexibility), kebiasaan bertanya secara kritis (critical reflection) dan sikap peka terhadap makhluk hidup dan lingkungan sekitar (sensitifity to living things and environment). Kurikulum mata pelajaran tersebut juga menggariskan bahwa salah satu tujuannya adalah untuk membina sikap positif mahasiswa terhadap lingkungan hidup.

Dengan memiliki pengetahuan IPA yang baik dan sikap-sikap diatas, diharapkan tertanam sikap yang sangat positif pada mahasiswa terhadap lingkungannya, sikap-sikap ilmiah tersebut dapat dicapai jika proses belajar mengajar IPA melibatkan berbagai metode mengajar khususnya eksperimen. Jadi, tidak sekedar interaksi satu arah dan menekankan hafalan (rote learning) tetapi belajar yang sesungguhnya (meaningful learning).

Penanaman sikap -sikap ilmiah melalui metode pengajaran yang tepat menurut Sholahudin (2001) cenderung akan sangat berpengaruh pada pembinaan sikap secara keseluruhan terutama sikap positif terhadap pelestarian lingkungan hidup. Namun demikian, terdapat beberapa kenyataan lain dalam proses belajar mengajar, khususnya pada IPA. Pertama, selama ini proses belajar mengajar IPA, dalam aplikasinya cenderung menekankan aspek kognitif, artinya konsepkonsep diajarkan sekedar pengetahuan, kurang dihayati dan direalisasikan sebagai sikap dan perilaku yang nyata. Lebih parah lagi, kenyataan ini ditunjang oleh system ujian yang cenderung hanya mengukur aspek kognitif. Evaluasi terhadap sikap yang terintegrasi dengan kognitif (pengetahuan) memang hampir tidak pernah dilakukan dalam proses belajar mengajar. Secara teoritis, pengetahuan akan berpengaruh terhadap sikap, akan tetapi tidak selalu demikian, perlu penanaman sikap yang benar.

\section{KESIMPULAN}

Bentuk dan prosedur model pembelajaran STS pada matakuliah Ekologi Manusia secara garis besar adalah mengikuti empat langkah yaitu invitasi, eksplorasi, penjelasan dan solusi. Karena kehidupan manusia sangat erat dengan lingkungan hidupnya, mahasiswa yang belajar tentang ekologi tentu saja sudah familiar dengan lingkungan sekitarnya. Pengetahuan mahasiswa dari lingkungan, dapat dijadikan modal dalam proses pembelajaran.

1. Pendekatan STS umumnya didominasi oleh metode tugas dan atau project. Perbedaan antar tugas dan projek terletak pada waktu penyelesaian pekerjaan. Tugas umumnya lebih singkat dari pada projek. Selain itu, pada projek siswa menentukan parameter pekerjaannya dengan seluruh petunjuk sedangkan pada tugas, parameter ditentukan guru. Pada projek, terbuka untuk berbeda jalan dan arahnya sedangkan tugas sangat dibatasi guru, projek cenderung student-centered learning approaches sedangkan tugas sebaliknya yaitu berpusat pada guru.

2. Hasil test awal (pretest) diketahui bahwa nilai rata-rata yang diperoleh responden hanya 17,0 dari 40 soal yang diajukan artinya jauh dibawah rata-rata. Standar deviasi dari rangkaian skor nilai adalah sekitar 4,8. Selanjutnya dari data hasil posttest ada kenaikan rata 22,7 yang menjawab dengan benar dari 40 soal. Dengan demikian, sudah dapat disimpulkan bahwa metode STS dapat meningkatkan prestasi mahasiswa.

3. Selanjutnya apakah ada pengaruhnya terhadap peningkatan kepedulian mahasiswa terhadap lingkungan hidup? Penelitian ini melakukan test skala sikap yang terdiri dari 40 soal dengan skala 1-5. Dari 40 pertanyaan diatas, kecenderungan responden dalam menjawab pertanyaan adalah positif. 
Jika diasumsikan bahwa antara jawaban responden memiliki kepedulian terhadap lingkungan hidup.

Menyadari dengan semakin menurunnya kondisi lingkungan hidup dewasa ini, semua pihak merasa perlu dan sangat mendesak menciptakan sarana yang tepat untuk menyampaikan informasi pelestarian lingkungan. Penyadaran akan keharusan pemeliharaan kelestarian lingkungan tidak akan cukup hanya melalui media atau pelatihan informal akan tetapi harus ditempuh melalui pendidikan yang terencana dengan baik seperti STS.

Materi pendidikan yang diberikan tidak hanya sebatas pada teori saja akan tetapi harus didukung dengan aplikasi praktis dan contoh konkrit dalam upaya pelestarian lingkungan. Kegiatan praktikum dan kunjungan ke lapangan juga harus diterapkan sebagai saran pendukung agar penyampaian materi lebih menarik tidak membosankan, sehingga akan berkesan permanen dan diharapkan terpola dalam kehidupan siswa terutama dengan menggunakan metode atau pendekatan STS.

\section{DAFTAR PUSTAKA}

Anonim. 2003. Pendekatan Kontekstual. Jakarta. Departemen Pendidikan Nasional.

Dikmenum, 1996/1997. Metodologi Pembelajaran, Bahan Penataran untuk Guru SMU, Depdikbud.

Hisyam Zaini, Bermawy Munthe, Sekar Ayu Aryani, 2002. Strategi Pembelajaran Aktif di Perguruan Tinggi, Yogyakarta:CTSD, IAIN Sunan Kalijogo.

Nana Sudjana, 1989. Dasar-Dasar Proses Belajar Mengajar, Bandung: Sinar Baru.

Paul Suparno, 1997. Filsafat Konstruktivisme dalam Pendidikan, Yogyakarta: Kanisius.

Poedjiadi, A. 2005. Sains Teknologi Masyarakat. Bandung. Remaja Rosdakarya

Ratna Wilis Dahar, 1989. Teori-Teori Belajar, Jakarta: Erlangga.
Slameto, 1988. Belajar dan Faktor-Faktor yang Mempengaruhinya, Jakarta: Bina Aksara.

Sukmadinata, N.S. 2004. Kurikulum dan Pembelajaran Kompetensi. Kesuma Karya. Bandung.

Sumaatmadja, N. 1980. Metodologi Pengajaran Ilmu Pengetahuan Sosial (IPS) penerbit Alumni. Bandung

Suryabrata, S. 1983. Metode Penelitian. PT. Raja Grafindo Persada. Jakarta. 